\title{
AN INTEGRATED APPROACH OF INTERPRETIVE STRUCTURAL MODELING (ISM) AND ANALYTIC HIERARCHY PROCESS (AHP) IN DEVELOPING INSTITUTIONAL SYSTEM OF THE BEEF CATTLE INDUSTRY
}

\author{
Sumarsono, Firwan Tan, Rudi Febriamansyah \\ Program of Agricultural Sciences, Agricultural Development Concentration, \\ Graduate Program, University of Andalas \\ rimbun.sumarsono@yahoo.co.id
}

\begin{abstract}
This study is aimed to know Structuring the sub element of Institutional System of Beef Cattle Industry. The methods used for data collection is by distributing questionnaires, interviews with experts and literature studies. Results of questionnaires and interviews with experts used to construct a hierarchy of election strategy for Beef Cattle industry development. Preparation of hierarchy elections industrial development strategy Beef Cattle using AHP technique. The formulation of a model with key elements in the element's goal is to realize a strong institutional element is the need for government support, elements of the perpetrator is a trader. While the key elements in the benchmarks is the increasing diversification of products Beef Cattle, element of constraint is the weak institutional system, lack of government support for industrial development Beef Cattle and the lack of guidance to the Breeders. For elements of the desired changes to the industrial development Beef Cattle is the formation of an independent group of cattle at the planting site Beef Cattle
\end{abstract}

Keyword: Interpretive Structural Modeling, Beef Cattle, Industrial Development

\section{INTRODUCTION}

Beef demand in Indonesia is likely to increase, but the rate of increase of domestic production is slower than the demand, so that Indonesia must import meat in quantities greater (Inounu, et al., 2007). According to Luthan (2009), almost $42 \%$ of domestic meat consumption is met from imports. It is estimated that Indonesia's population beef consumption in 2020 will increase 2-3 times that of the average current consumption of less than $2 \mathrm{~kg} / \mathrm{capital} / \mathrm{year}$, so that Indonesia is feared to be an importer of cattle in the world (Diwyanto, 2008). Without a serious attempt, then in 2015 almost $55 \%$ of meat consumption society will be met from cattle and beef imports, while Indonesia has the potential for a sizeable local livestock managed by 4.6 million households (Luthan, 2009). Last livestock census in 2011 showed that beef cattle population reached 14.82 million head (DG PKH, 2012), more than is expected. This potential should be empowered to reduce dependence on imported cattle.

Cultivation of beef cattle competitiveness has a great opportunity to address the challenges and opportunities. Indonesia has the land resources and plants that have the potential to support the development of medium and largescale livestock. Along with the increasing use of land for farming activities, the development of livestock in certain areas should be done in an integrated manner that is mutually beneficial. Land use, especially outside Java, is not optimal because it is generally only used for one type of livestock enterprises. 
Table 1

The Number of Beef Cattle at Districts in The Province of Jambi, 2013

\begin{tabular}{|c|c|c|c|c|c|c|}
\hline \multirow[t]{2}{*}{ Districts } & \multicolumn{6}{|c|}{ Years } \\
\hline & 2008 & 2009 & 2010 & 2011 & 2012 & 2013 \\
\hline Kerinci & 20439 & 17064 & 19743 & 11.322 & 20408 & 11246 \\
\hline $\begin{array}{l}\text { Merangin } \\
\text { Sarolangun }\end{array}$ & $\begin{array}{r}15165 \\
9702\end{array}$ & $\begin{array}{l}16505 \\
11168\end{array}$ & $\begin{array}{l}16886 \\
11711\end{array}$ & $\begin{array}{r}14.398 \\
7.811\end{array}$ & $\begin{array}{r}16096 \\
7266\end{array}$ & $\begin{array}{r}14322 \\
7735\end{array}$ \\
\hline $\begin{array}{l}\text { Batang Hari } \\
\text { Muaro Jambi }\end{array}$ & $\begin{array}{r}9061 \\
14743\end{array}$ & $\begin{array}{r}8997 \\
16354\end{array}$ & $\begin{array}{r}9416 \\
20532\end{array}$ & $\begin{array}{r}7202 \\
14827\end{array}$ & $\begin{array}{r}8065 \\
14476\end{array}$ & $\begin{array}{r}7126 \\
14751\end{array}$ \\
\hline Tanjab Timur & 10802 & 11458 & 12629 & 12344 & 14703 & 12268 \\
\hline Tanjab Barat & 8726 & 11075 & 12677 & 6564 & 7121 & 6488 \\
\hline Tebo & 22546 & 23742 & 24191 & 17298 & 21229 & 17222 \\
\hline Bungo & 36435 & 42239 & 44147 & 22867 & 23980 & 22791 \\
\hline Kota Jambi & 1423 & 1565 & 1180 & 2102 & 2844 & 2026 \\
\hline $\begin{array}{l}\text { Kota } \\
\text { Penuh }\end{array}$ & 0 & 4359 & 4601 & 3150 & 3411 & 3074 \\
\hline Propinsi Jambi & 149042 & 164526 & 177710 & 119888 & 139599 & 119049 \\
\hline
\end{tabular}

Source: Primary Data Processed in, 2014

Supply Chain Management (SCM) or the supply chain is a system where an organization channeling the production of goods and services to customers (Chopra and Meindel, 2007). There are some major players who have an interest in supply chain management, namely: Suppliers, Manufacturers, Distribution, Retail Outlets, and Customer. Relations chain of actors can be in the form of a chain connected to one another. The main purpose of SCM is: submission / delivery of products in a timely manner in order to satisfy customers, reduce costs, improve all the results of the entire supply chain companies. One aspect that is important in the smooth supply chain of a product is the institutional aspect. Base effective behavior characterized relations with the acquisition of financial and non-financial benefits that have members of suppliers interconnected in order to increase the flow. Institutional pattern is needed as a means to coordinate all activities ranging from breeding, cultivation and processing of Beef Cattle (Indrajit and Djokopranoto, 2003).

Cows are a major meat producer in Indonesia. Beef consumption reached 19 percent of total national meat consumption (Directorate General of Livestock, 2009). Beef consumption tends to increase from year to year. In 2006 to 4.1 $\mathrm{kg} / \mathrm{capita} /$ year increased to $5.1 \mathrm{~kg} / \mathrm{capita} /$ year in 2007. However, the increase in meat consumption is not offset by an increase in livestock population (imbalance between supply and demand), so it is balanced by imports beef each year continues to increase around 360 thousand tons in 2004 to 650 thousand tons in 2008 (Luthan, 2009).

To reduce Indonesia's dependence on imported beef cattle, Ministry of Agriculture re-launched a program of self-sufficiency in meat in 2014 by conducting in-depth studies through the program "Accelerate Achievement of Self-Sufficiency Beef (P2SDS)". The activities carried out include the revitalization program with the distribution of seed breeding cattle to various provinces of potential to be developed intensively. Ideally, the increase in the cattle population reaches at least 7 percent per year (Director General of Animal Husbandry, 2009). 


\section{Agriekonomika, ISSN 2301-9948

Beef cattle are ruminants kept most Breeders in Jambi province. Beef cattle population in 2003 was recorded as many as 145845 head where there is an average increase of $2.66 \%$ over the last 3 years. Nation of cattle that are diverse, generally in low-lying areas (Jambi region of Central and Eastern parts) based Bali cattle. Where as in the plateau area of Kerinci and most Merangin (western region) are generally based PO cow. With the passage of the IB program, up to now has been widely found the types of cattle crosses in several development centers.

The aim of this study is to formulate and develop an institutional system of the Beef Cattle industry using the Interpretive Structural Modeling (ISM) and Analytic Hierarchy Process (AHP).

Interpretive Structural Modeling (ISM) was first proposed by J. Warfield in 1973 to analyze the complex socio-economic system. ISM is a learning process with a computer-assisted that allows individuals or groups to develop a map of complex the relationship between the various elements involved in complex situations. The basic idea is use of experienced experts and practical knowledge to elaborate complex systems into several sub-systems (elements) and build a multilevel structural model (George and Pramod, 2014). ISM helps to impose order and direction on the complex relationships among elements of a system, and this is one of the requirements to be addressed for the development of an efficient performance measurement system. (Takkar, 2007)

Analytical Hierarchy Process (AHP) was introduced by Thomas L. Saaty in the 1970 and 1994. According to Saaty (2008), The Analytic Hierarchy Process (AHP) is a theory of measurement through pairwise comparisons and relies on the judgements of experts to derive priority scales. It is these scales that measure intangibles in relative terms. The comparisons are made using a scale of absolute judgements that represents, how much more, one element dominates another with respect to a given attribute.

AHP is a functional hierarchy with the main input of human perception. Because it uses inputs of human perception, AHP can be used to process the data that is both qualitative and quantitative. In addition AHP has the ability to solve problems of multi objective and multi-criteria based on a comparison of the preferences of each element in the hierarchy. (Triantaphyllou and Mann, 1995).

\section{METHODOLOGY}

This research was conducted in Jambi Province and was conducted from March to April 2014.The methods used for data collection is by distributing questionnaires, interviews with experts and literature studies. Results of questionnaires and interviews with experts used to construct a hierarchy of election strategy Beef Cattle industry development. Preparation of hierarchy elections industrial development strategy Beef Cattle using AHP technique. AHP makes the selection process very transparent. It also reveals the relative merits of alternative solutions for a Multi Criteria Decision Making (MCDM) problem. According to Kumar et.al (2009), AHP approach is a subjective methodology so the information and the priority weights of elements may be obtained using direct questioning or a questionnaire method.

As for determining the element sand their sub elements disposal in formulating the institutional system of Beef Cattle industry was used ISM technique. As Attri, et al (2013), mentioned that ISM models help to find the key factor related to problem or issue. After identification of key factor or element, strategy may be developed for dealing issue. 


\section{RESULTS AND DISCUSSION}

One of the key success factors of an activity was the institutional system. The main role of the institution is to reduce clutter to determine a stable structure for human interaction. Institutional stability can be changed according to the time change as a process towards improvement and development. In general, institutional development goal is to achieve the degree of fulfillment of human needs in a better way in a sense, the location of resources efficiently and effectively which can be accepted by all communities fairly. Therefore, specifically an institution must be able to be the vehicle for access are fair to input factors, able to provide the rules and the reference fair for every actor in the institutions in order to achieve efficiency and effectiveness in resource allocation to all the elements involved, and able to distribute the results of the use of resources to achieve the desired objectives. Thus the institutional development objectives is to give a greater role and balanced for all components involved in the decision making process.

\section{Identification Element and Sub Element to Develop Institutional System of Beef Cattle Industry using ISM}

Institutional system which used ISM can be described on 6 elements consisting of (1) Element of Actors, (2) Element of Needs, (3) Element of Purpose, (4) Element of Constraints,(5) Elements of Benchmark, and (6) Element of Change, Each these elements consist of a number of sub-elements, including.

\section{Element of Actors}

Needs of actors in the development of industry Beef Cattle can be interpreted as the actors involved in efforts to develop industry Beef Cattle in Jambi Province. Sub elements of these actors are: Breeders (P1), Cow Traders (broker) (P2), Slaughter house (P3), Consumer (P4), Related Industry (P5), Department of Animal Husbandry (P6), Department of Cooperatives (P7), Financial Institutions (P8), Department of Industry and Trade (P9), and the Center for Research and Development (P10).

\section{Element of Needs}

Element of Needs to support the needs of industrial development of Beef Cattle. A number sub element of elements of needs are as follows: Development of businesses (B1), capital guarantee (B2), the government support (B3), utilization of container business (B4), Quality Assurance (B5), guarantee of quantity (B6), and guarantee of the continuity production (B7).

\section{Element of Purpose}

A number of sub-elements of the element of purpose are as follows: Achieve strong institutional (T1), Increase market share (T2), Expanding employment (T3), development of conducive business climate (T4), Improving the skills of Human Resources (T5), increase revenue (T6), increase farmer income (T7), Making marketing channels (T8), improve the quality Beef Cattle (T9), and increase product diversification of Beef Cattle (T10).

\section{Element of Benchmark}

Element of the benchmark should be required as a reference for the success of the destination. A number sub element of the elements of the 
benchmarks are as follows: Created a strong institutional (U1), Increased market share (U2), Increasing the opinion Breeders (U3), creation of new jobs (U4), Increased product diversification Beef Cattle (U5), Increased quality and Beef Cattle (U6).

\section{Element of Constraints}

Sub element of constraint is as follows: Weak institutional system (K1), Weak Farmers can access capita in financial institutions (K2), networks and cooperation for mutual support among employers unformed (K3), less consistently of breeder stomainta in the quality (K4), lack of government support in the development of Beef Cattle (K5), lack of education and skills (K6), and the lack of development of the Breeder (K7).

\section{Element of Change}

Sub elements of the element of change are as follows: The independent farmer groups are formed in locations of Beef Cattle (R1), expansion of employment in agribusiness of Beef Cattle (R2), Empowerment of community surrounding locations of Beef Cattle (R3), the area expansion of Beef Cattle's land (R4), Application of information technology (R5), and various types of processed products of Beef Cattle (R6).

\section{Structuring the sub element of Institutional System of Beef Cattle Industry using ISM and AHP Element of Actors}

Structuring the elements of actors, consisting of 10 sub-elements, using ISM and AHP will generate the reachability matrix (RM), hierarchical model structure and classification of sub element. The results of expert assessment of the contextual relationship between the sub-elements of these actors produce SSIM (Structural Self Interpretative Matrix). The assessment results are converted into reachability matrix $(\mathrm{RM})$. Reach ability matrix is then converted into a matrix that meets $\mathrm{RM}$ transitivity rule. The final results matrix $\mathrm{RM}$ that meets the rules of transitivity as follows:

Based on research, Figure 1 shows that the sub-elements that have the highest thrust is trader (P2). Traders will push sub Breeders element (P1), Slaughter house (P3), related industries (P5) to affect the elements of the perpetrator. Furthermore, these elements will influence consumers (P4), the Department of Animal Husbandry (P6), the Department of Cooperatives (P7), and Financial Institutions (P8). Those sub elements will lead to sub-elements of the Department of Industry and Trade (P9), Center for Research and Development (P10) in developing of Beef Cattle industry. At this last level is a sub element which has high power driver but it requires momentum from the previous level.

Based on the results of the sub-elements classification into four matrix sectors, the sub elements that go into dependent sectors are sub elements of the Department of Animal Husbandry (P6), consumers (P4) and financial institutions (P8). The third sub elements are dependent on other elements. While sub element Breeders (P1), traders (P2), Slaughter house (P3) and financial institutions (P8) is in linkage sectors. The fourth sub-elements need to be assessed carefully. Based on the level of thrust and power drivers, the sub- 
elements of traders (P2) is a key element in the elements of industrial development system actors Beef Cattle.

\section{Element of Needs}

The final results of RM matrix of the element of needs which meets the rules of transitivity as shown in Table 2.

Table 2

Final Results Reachability Matrix Elements of Needs

\begin{tabular}{|c|c|c|c|c|c|c|c|c|c|}
\hline \multirow{2}{*}{$\begin{array}{l}\text { Sub Element } \\
\text { of Needs Code }\end{array}$} & \multicolumn{7}{|c|}{ Sub Element of Needs Code } & \multirow[t]{2}{*}{ DP } & \multirow[t]{2}{*}{ EK } \\
\hline & B1 & B2 & B3 & B4 & B5 & B6 & B7 & & \\
\hline B1 & 1 & 1 & 0 & 1 & 0 & 1 & 0 & 4 & 3 \\
\hline B2 & 0 & 1 & 1 & 1 & 0 & 0 & 0 & 3 & 4 \\
\hline B3 & 1 & 1 & 1 & 1 & 1 & 1 & 1 & 7 & 1 \\
\hline B4 & 1 & 0 & 1 & 1 & 1 & 0 & 1 & 5 & 2 \\
\hline B5 & 1 & 1 & 0 & 0 & 1 & 1 & 1 & 5 & 2 \\
\hline $\mathrm{B} 6$ & 1 & 0 & 0 & 0 & 0 & 1 & 1 & 3 & 4 \\
\hline B7 & 1 & 0 & 0 & 0 & 1 & 0 & 1 & 3 & 4 \\
\hline D & 6 & 4 & 3 & 4 & 4 & 4 & 5 & & \\
\hline $\mathrm{L}$ & 1 & 3 & 4 & 3 & 5 & 3 & 2 & & \\
\hline
\end{tabular}

Source: Primary Data Processing in, 2014

\section{Element of Purpose}

The final results matrix RM of the element of purpose which meets the rules of transitivity as shown in Table 3.

Table 3

Final Results Reachability Matrix Elements of Purpose

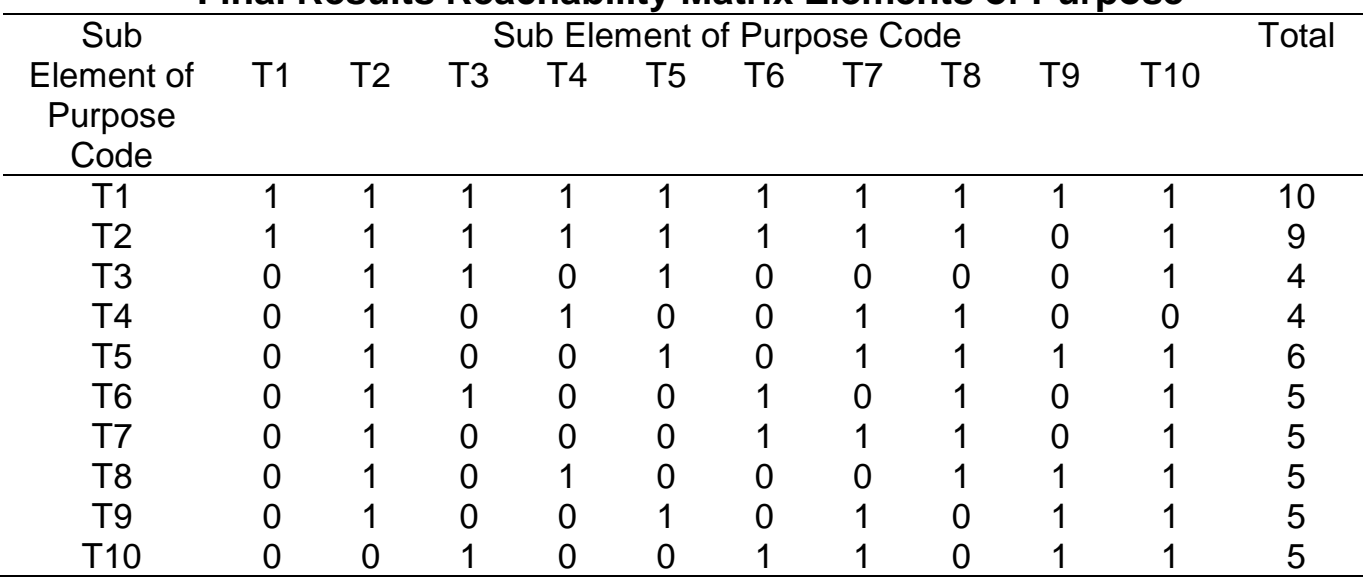

Source: Primary Data Processing, 2014

Based on the final matrix RM can be made hierarchical connectivity between sub-elements on the element of purpose. The result show that a hierarchy of sub-elements on the connectedness of the element of purpose for the institutional system of Beef Cattle industry. The hierarchy is based on the final matrix RM in Table 3. Sub elements, achieve strong institutional ( $\mathrm{TI}$ ) has the highest thrust to the sub elements increase revenue (T6), increase farmer income (T7) and effective marketing channels (T8). To Increase product diversification Beef Cattle (T10), expanding employment (T3) and the development of a conducive business climate (T4) needs the support of level- 
previous level, where the sub-elements of a strong institutional realize the highest thrust.

\section{Element of Benchmark}

The final results matrix RM, elements of benchmarks that meet the rules of transitivity can be seen at Table 4 .

Table 4

Final Results Reachability Matrix Elements of Benchmark

\begin{tabular}{|c|c|c|c|c|c|c|c|}
\hline \multirow{2}{*}{$\begin{array}{l}\text { Sub Element of Benchmark } \\
\text { Code }\end{array}$} & \multicolumn{6}{|c|}{ Sub Element of Benchmark Code } & \multirow[t]{2}{*}{ total } \\
\hline & U1 & $\mathrm{U} 2$ & U3 & $\mathrm{U} 4$ & $\mathrm{U} 5$ & U6 & \\
\hline $\mathrm{U} 1$ & 1 & 1 & 1 & 0 & 0 & 0 & 3 \\
\hline U2 & 0 & 1 & 1 & 1 & 1 & 0 & 4 \\
\hline U3 & 1 & 1 & 1 & 1 & 0 & 0 & 4 \\
\hline U4 & 0 & 1 & 1 & 1 & 0 & 0 & 3 \\
\hline U5 & 1 & 1 & 1 & 1 & 1 & 1 & 6 \\
\hline U6 & 1 & 1 & 1 & 0 & 1 & 1 & 5 \\
\hline
\end{tabular}

Source: Primary Data Processing in, 2014

Based on the final matrix RM can be made hierarchical connectivity between sub-elements on the element of benchmark.

Based on the hierarchy of the sub-elements, grouped into four matrix power driver-dependent relationship. Sub elements of the increasing diversification of product Beef Cattle (U5) and improve the quality Beef Cattle (U6) are the independent sector where the sub element can not be affected by the sub-elements of the other, but it is able to affect the other. While sub element creates a strong institutional (U1) and the creation of new jobs (U4) is very be affected by other sub-elements, such as sub elements are dependent on the sector. In the sector of linkage there are sub elements to increase market share (U2) and increase revenues Breeders (U3) needs to be studied carefully. Based on the above-mentioned, the sub-elements of the increasing diversification of product Beef Cattle (U5) is a key element of the sub-elements of the institutional system benchmarks Beef Cattle industry development.

\section{Element of Constraints}

The final results matrix RM, element constraints, which meets the transitivity rule can be seen in Table 6 .

Table 6

Final Results Reachability Matrix Elements of Constraints

\begin{tabular}{|c|c|c|c|c|c|c|c|c|c|}
\hline \multirow{2}{*}{$\begin{array}{l}\text { Sub Element of } \\
\text { Constraints Code }\end{array}$} & \multicolumn{7}{|c|}{ Sub Element of Constraints Code } & \multirow{2}{*}{ DP } & \multirow{2}{*}{ EK } \\
\hline & K1 & $\mathrm{K} 2$ & $\mathrm{~K} 3$ & K4 & K5 & K6 & K7 & & \\
\hline $\mathrm{K} 1$ & 1 & 1 & 1 & 1 & 1 & 1 & 1 & 7 & 1 \\
\hline K2 & 1 & 1 & 1 & 1 & 0 & 0 & 0 & 4 & 3 \\
\hline K3 & 1 & 0 & 1 & 1 & 1 & 0 & 0 & 4 & 3 \\
\hline K4 & 0 & 1 & 0 & 1 & 1 & 1 & 1 & 5 & 2 \\
\hline K5 & 1 & 1 & 1 & 1 & 1 & 1 & 1 & 7 & 1 \\
\hline K6 & 0 & 0 & 1 & 1 & 0 & 1 & 1 & 4 & 3 \\
\hline K7 & 1 & 1 & 1 & 1 & 1 & 1 & 1 & 7 & 1 \\
\hline D & 5 & 5 & 6 & 7 & 5 & 5 & 5 & & \\
\hline $\mathrm{L}$ & 3 & 3 & 2 & 1 & 3 & 3 & 3 & & \\
\hline
\end{tabular}

Source: Primary Data Processing in, 2014 
Based on the final matrix RM can be made hierarchical connectivity between sub-elements on the element of constraints, as shown in Figure5. Sub elements of weak institutional system (K1), lack of government support in the development of beef cattle (K5) and a lack of guidance to farmers (K7) is a sub element that has thrust the highest of the obstacles encountered on the system Institutional development of beef cattle industry, Sub elements will encourage farmers less consistently maintain the quality (K4). Sub weak element breeders can access capital in financial institutions (K2), the network of mutual support and cooperation between employer unformed (K3), lower levels of education and skills (K6) occurs due to the strong encouragement of other sub-elements.

\section{Element of Change}

The final results matrix RM elements of change that meets the rules of transitivity can be seen in Table 7 .

Table 7

Final Results Reachability Matrix Elements of Change

\begin{tabular}{|c|c|c|c|c|c|c|c|c|}
\hline \multirow{2}{*}{$\begin{array}{l}\text { Sub Element of } \\
\text { Change Code }\end{array}$} & \multicolumn{6}{|c|}{ Sub Element of Change Code } & \multirow{2}{*}{ DP } & \multirow{2}{*}{ EK } \\
\hline & $\mathrm{R} 1$ & $\mathrm{R} 2$ & R3 & R4 & R5 & $\mathrm{R} 6$ & & \\
\hline $\mathrm{R} 1$ & 1 & 1 & 1 & 1 & 1 & 1 & 6 & 1 \\
\hline $\mathrm{R} 2$ & 0 & 1 & 1 & 0 & 1 & 1 & 4 & 3 \\
\hline R3 & 0 & 1 & 1 & 1 & 1 & 1 & 5 & 2 \\
\hline R4 & 0 & 1 & 1 & 1 & 0 & 1 & 4 & 3 \\
\hline R5 & 1 & 0 & 1 & 0 & 1 & 1 & 4 & 3 \\
\hline R6 & 1 & 0 & 1 & 0 & 0 & 1 & 3 & 4 \\
\hline D & 3 & 4 & 6 & 3 & 4 & 6 & & \\
\hline $\mathrm{L}$ & 3 & 2 & 1 & 3 & 2 & 1 & & \\
\hline
\end{tabular}

Source: Primary Data Processing in, 2014

Based on the final matrix RM can be made hierarchical connectivity between sub-elements on the element of change. Hierarchical relationship between the sub-elements. Sub-element of the formation of an independent group of cattle at locations Livestock Beef Cattle (RI) has a very strong impetus and influence on the community around the region Empowerment Livestock Beef Cattle(R3). While sub-element Expansion of jobs in agribusiness Beef Cattle(R2), expansion of the area of land Livestock commodity Beef Cattle (R4) and the application of information technology agribusiness Beef Cattle including about quality Beef Cattle(R5) is affected by the sub-elements of the empowerment of regional communities Area Livestock Beef Cattle. Sub diverse elements processed products Beef Cattle (R6) is influenced sub-sub elements of other elements.

Results structuring of all elements in the institutional system of Beef Cattle industry produce sub key elements for each element, as shown in Figure 1. According to Figure 1, realize a strong institutional need full support from the government and key players are traders, so changes desirable that the formation of an independent group of animals capable of being a measure with increasing product diversification of Beef Cattle. This would overcome the obstacles faced particularly weak institutional system, lack of government support and lack of guidance to breeders. These constraints can be overcome with the strong support from the government to develop the Beef Cattle industry. 


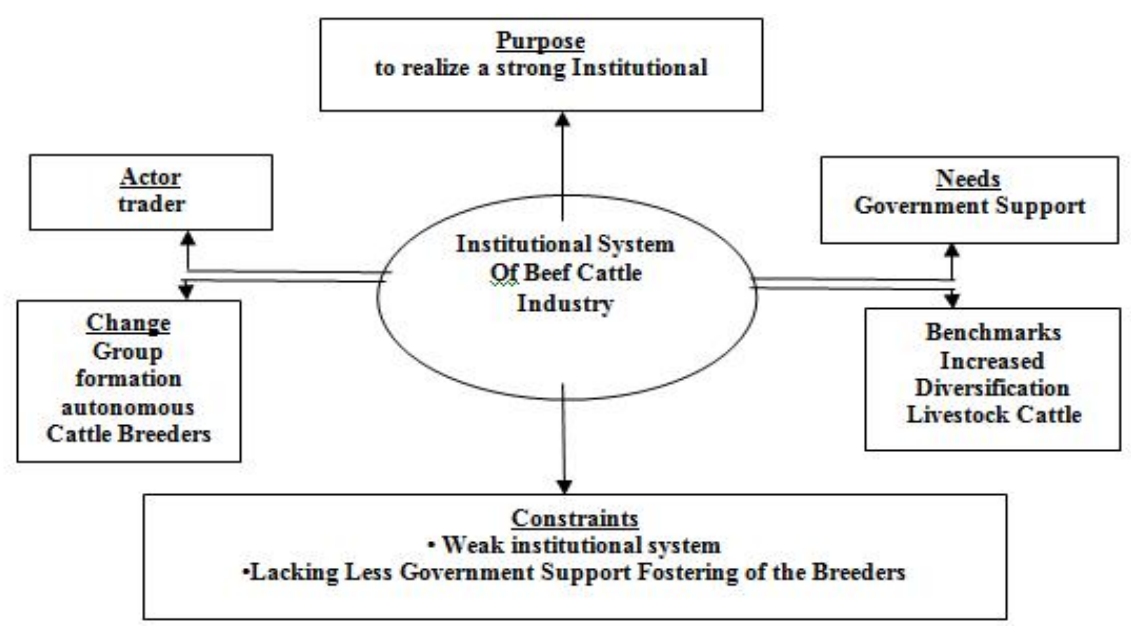

Source: Primary Data Processing in, 2014

Figure 1

\section{Element structure of Institutional System of Beef Cattle Industry}

\section{Selection of Beef Cattle Industry Development Strategies with AHP}

The hierarchical structure of beef cattle industry development strategies have four levels. The first level is the actors directly involved in the development of industry Beef Cattle. The second level is a goal which is the goal of developing a strategy selection. The third level is the business criteria that must be considered for the development of industry Beef Cattle. While the fourth level is an alternative strategy for the development of industrial Beef Cattle terms of institutional. Based on the results of weighting the value of each element on every level, it can be seen the results of the hierarchy as follows:

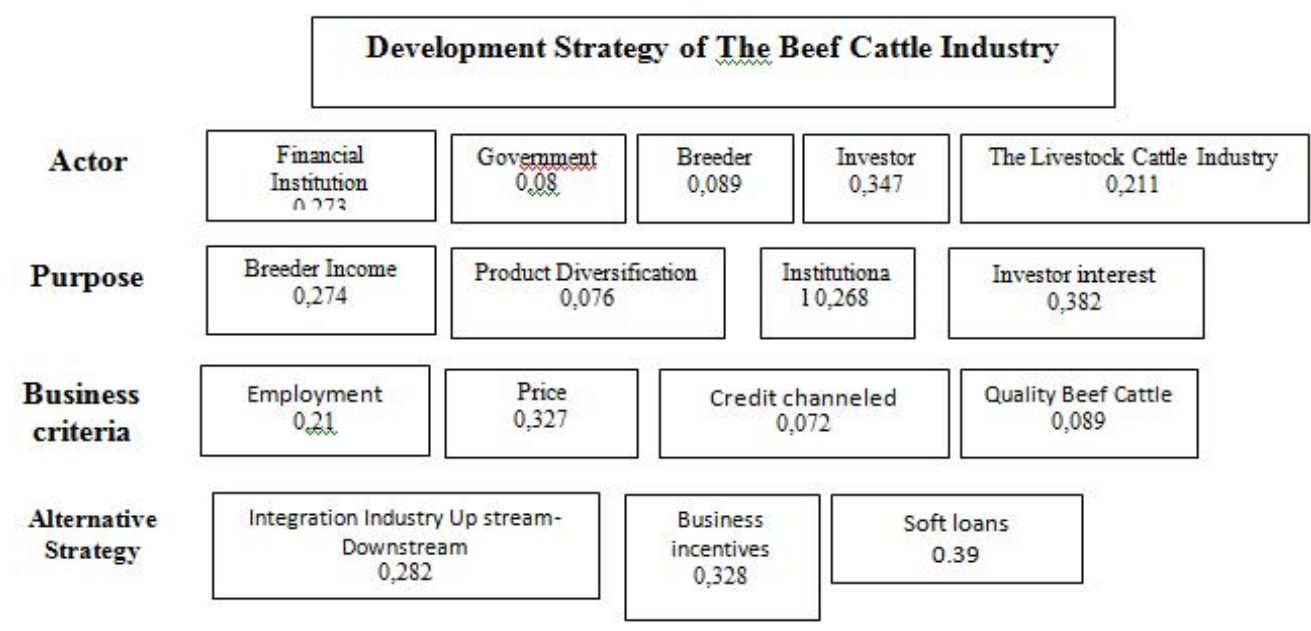

Source: Primary Data Processing in, 2014

Figure 2

Hierarchy Structure, Development Strategy of The Beef Cattle Industry 


\section{CLOSING}

The formulation of a model institutional system Beef Cattle industry development with key elements in the element's goal is to realize a strong institutional element is the need for government support, elements of the perpetrator is a trader. While the key elements in the benchmarks is the increasing diversification of products Beef Cattle, element of constraint is the weak institutional system, lack of government support for industrial development Beef Cattle and the lack of guidance to the Breeders. For elements of the desired changes to the industrial development Beef Cattle is the formation of an independent group of cattle at the planting site Beef Cattle. Governments need to provide support to the development of industry Beef Cattle Breeders in an effort to increase revenue.

\section{REFERENCES}

Attri, Rajesh. 2013. Interpretive Structural Modelling (ISM) approach: An Overview. Research Journal of Management Sciences 2(2): 3-8

Arnold JR dan SN Chapman. 2004. Introduction to Materials Management. New Jersey.

Diwyanto, K. 2008. Pemanfaatan Sumber Daya Lokal Dan Inovasi Teknologi Dalam Mendukung Pengembangan Sapi Potong Di Indonesia. Pengembangan Inovasi Pertanian 1(3): 173-188.

George, J P and Pramod, V. R. (2014). An Interpretive Structural Model (Ism) Analysis Approach In Steel Re Rolling Mills (SRRMS) Impact: International. Journal Of Research In Engineering \& Technology 2(2) : 161-174.

Handfield RB dan EL. Nichols Jr. 2002. Supply Chain Redesign. Prentice Hall. New York

Indrajit RE dan R. Djokopranoto. 2003. Konsep Manajemen Supply Chain, Cara Baru Memandang Mata Rantai Penyediaan Barang. Penerbit Grassindo. Jakarta

Inounu, I. E. Martindah, R.A. Saptati dan A. Priyanti. 2007. Potensi Ekosistem Pulau-Pulau Kecil Dan Terluar Untuk Pengembangan Usaha Sapi Potong. Wartazoa 7(4): 156-164.

Kumar, S. Parashar, N dan Haleem, A. 2009. Analytical Hierarchy Process Applied to Vendor Selection Problem: Small Scale, Medium Scale and Large Scale Industries. Business Intelligence Journal. 2(3): 355-362

Luthan, F. 2009. Implementasi Program Integrasi Sapi Dengan Tanaman: Padi, Sawit, Dan Kakao Di Indonesia. Prosiding Workshop Nasional Dinamika dan Keragaan Sistem Integrasi Ternak-Tanaman: Padi, Sawit, Kakao. Pusat Penelitian dan Pengembangan Peternakan, Bogor. 


\section{Agriekonomika, ISSN 2301-9948 \\ e ISSN 2407-6260 \\ Volume 5, Nomor 1}

Marimin. 2004. Teknik dan Aplikasi Pengambilan Keputusan Kriteria Majemuk. Penerbit Grassindo. Jakarta.

Rukmana, D. 1998. Budidaya Peternakan Sapi Potong. Penerbit Kanisius. Jakarta

Saxena, JP. 1992. Hierarchy and classification of program plan elements using Interpretive Structural Modeling System. Manila Practice Journal 5(6): 651-670.

Saaty, Thomas L. 2008. Decision Making With The Analytic Hierarchy Process. International Journal of Services Sciences 1(1): 83-98

Takkar, J. 2007. Development of a Balanced Scorecard, An Integrated Approach of Interpretive Sructural Modeling (ISM) and Analytic Network Process (ANP). International Journal of Productivity and Performance Management 56(1): 25-59.

Chopra, S dan P. Meindel. 2007. Supply Chain Management: Strategy, Planning and Operation. Pearson Prentice Hall. 